\title{
The use of phytochemicals as fumigants for the control of stored product insect pests
}

\begin{abstract}
The current study is aimed to evaluate the potential use of the known isothyiocyanates, as compared to a new isothyiocyanate (ITC) isolated from Eruca sativa (salad rocket) as fumigants for the control of stored product insects. The biological activity of methyl iodide $\left(\mathrm{CH}_{3} \mathrm{I}\right)$, carbon disulphide $\left(\mathrm{CS}_{2}\right)$, benzaldehyde $\left(\mathrm{C}_{7} \mathrm{H}_{6} \mathrm{O}\right)$ and essential oils were also evaluated. The toxicity of the various fumigants was assessed against adults and larvae of a number of major stored product insects. ITCs are known to have high toxicity and only very low concentrations are needed for the control of stored product insects. Eruca sativa is used worldwide as a food supplement. Methylthio butyl ITC, the main bioactive component in this plant has high toxicity against insects, but lower mammalian toxicity as compared to other active ITCs. This makes this compound a potential candidate for insect control. Comparative studies with $\mathrm{CH}_{3} \mathrm{I}_{2} \mathrm{CS}_{2}$ and $\mathrm{C}_{7} \mathrm{H}_{6} \mathrm{O}$ showed that the first was the most active compound against stored product insects followed by the second and third. $\mathrm{C}_{7} \mathrm{H}_{6} \mathrm{O}$ was found active, but very sorptive; therefore it was less effective against insects. The activity of a large number of essential oils (EOs) isolated from aromatic plants was also evaluated.
\end{abstract}

Key words: isothyiocyanate, essential oils, stored product pests, fumigation.

\section{INTRODUCTION}

In developing countries, where modern storage technologies have not been introduced, the post harvest losses caused by insects and other bioagents in cereals and other durable commodities, may amount to $10-40 \%$ (Raja et al., 2001). Fumigation is still one of the most effective methods for the protection of stored grain and dry food from insect infestation. At present, mainly two fumigants are still in use: methyl bromide and phosphine. The first one is being mostly phased out in developed countries due to its ozone depletion effect (WHO, 1995; Shaaya \& Kostyukovsky, 2006) the role of phosphine in grain protection has increased and stands as the main alternative to methyl bromide. Lately, insect resistance to phoshphine has become an important issue for effective grain treatment (Rajendran \& Karanth, 2000). Therefore, there is an urgent need for new strategies to focus on a search for alternative fumigants for the control of stored product insects. In this paper we present a comprehensive study to evaluate the poten- 
tial use of EOs, $\mathrm{CH}_{3} \mathrm{I}, \mathrm{CS}_{2}, \mathrm{C}_{7} \mathrm{H}_{6} \mathrm{O}$ and ITCs for the control of stored product insects.

Mustard family (Brassicaceae) seed contain isothyiocyanates (ITCs), volatile essential oils that are known to possess insecticidal activity. By screening a number of various species of Brassicaceae seeds, it was possible to isolate from seed oils of $\mathrm{Si}$ napis arvensis, Eruca sativa and Diplotaxis spp, an unknown ITC at concentrations of $98 \%, 92 \%$ and $33 \%$ respectively. This compound was identified later, as methylthio butyl ITC.

Fumigation is one of the most popular methods for the control of cultural properties insects.

The total prohibition of the use of methyl bromide in developed countries makes the use of these fumigants a potential candidate for the control of cultural properties insect pests.

\section{MATERIALS AND METHODS}

The tested stored product insects were laboratory strains of Sitophilus oryzae (L.), Rhyzopertha dominica (F.), Oryzaephilus surinamensis (L.), Tribolium castaneum (Herbst), Trogoderma granarium (Everts) and Plodia interpunctella (Hübner).

The ITCs were obtained by putting $100 \mathrm{~g}$ ground seeds into round bottom flask containing buffer solution ( $1 \%$ ascorbic acid). The flask is held in a water bath at $70^{\circ} \mathrm{C}$ for two hours to facilitate the hydrolysis of sinigrin to ITC by the enzyme myrosinase which is found inside the seeds. The second step is steam distillation with use of the Dean-Stark apparatus (Leoni et al., 1997). The yellow upper layer is then separated and extracted with petroleum ether. Finally, the petroleum ether is evaporated under a stream of air. The unknown ITC obtained from the seeds of Eruca sativa was identified as methylthio butyl isothiocyanate by gas chromatography (GC), nuclear magnetic resonance (NMR) and infra-red (IR) spectroscopy.

In order to isolate bioactive EOs we screened a large number of EOs obtained from aromatic plants. The EOs extracted by steam distillation from freshly harvested leaves and stems, and their main constituents, were isolated by methods cited in Shaaya et al. (1991; 1997). USA.

$\mathrm{CS}_{2}, \mathrm{CH}_{3} \mathrm{I}, \mathrm{C}_{7} \mathrm{H}_{6} \mathrm{O}$ were purchased from Sigma Chemical Company, St Louis, MO.

Two types of bioassays were performed to evaluate the activity of the fumigants. The first screening of the compounds was space fumigation in glass chambers of 3.41 capacity (Shaaya et al., 1991). The highly active compounds were then assayed in simulation glass columns (10 cm in diameter x $120 \mathrm{~cm}$ in height) filled to $70 \%$ by volume with wheat (11\% moisture content). The insects were introduced in cages, each holding 20 insects of the same species and food supply. Groups of four cages were suspended by a steel wire at different heights from the bottom of the column. Percentage insect mortality was then determined one to seven days after treatment. 


\section{RESULTS}

\section{Studies with essential oils (EOs)}

Using space fumigation methodology, two EOs obtained from Lamiaceae plants, were found to be the most potent fumigants as compared with all other essential oils obtained from a large number of aromatic plant species tested against stored-product insects. The main component of one of the EOs was pulegone, and of the other, not yet totally identified, called SEM 76. In space fumigation these two volatiles caused total mortality of all adults tested at very low concentration of $0.5-1.0 \mu \mathrm{l} / \mathrm{L}$ air and exposure time of 1 day. For comparison we tested also limonene which represents most of the other EOs tested, and was found much less effective (Tab. 1).

\begin{tabular}{|c|c|c|c|c|c|c|}
\hline \multirow[b]{2}{*}{ Fumigation } & \multirow[b]{2}{*}{ Compound } & \multirow{2}{*}{$\begin{array}{l}\text { Conc. } \\
\mu \mathrm{l} / \mathrm{L}\end{array}$} & \multicolumn{4}{|c|}{$\%$ Mortality ( 7 days after treatment) } \\
\hline & & & $\begin{array}{c}\text { Rhyzopertha } \\
\text { dominica }\end{array}$ & $\begin{array}{l}\text { Oryzaephilus } \\
\text { surinamensis }\end{array}$ & $\begin{array}{c}\text { Sitophilus } \\
\text { oryzae }\end{array}$ & $\begin{array}{l}\text { Tribolium } \\
\text { castaneum }\end{array}$ \\
\hline \multirow{4}{*}{ Space } & \multirow{2}{*}{ SEM 76} & 0.5 & 100 & 100 & 100 & 87 \\
\hline & & 1 & 100 & 100 & 100 & 100 \\
\hline & Pulegone & 0.5 & 100 & 100 & 100 & 100 \\
\hline & Limonene & 0.5 & 27 & 27 & 24 & 0 \\
\hline \multirow{5}{*}{ Columns } & \multirow{5}{*}{ SEM 76} & 70 & 100 & 100 & 70 & 66 \\
\hline & & $70+$ & \multirow{2}{*}{100} & \multirow{2}{*}{100} & \multirow{2}{*}{100} & \multirow{2}{*}{100} \\
\hline & & $15 \% \mathrm{CO}_{2}$ & & & & \\
\hline & & $50+$ & \multirow{2}{*}{100} & \multirow{2}{*}{100} & \multirow{2}{*}{100} & \multirow{2}{*}{96} \\
\hline & & $15 \% \mathrm{CO}_{2}$ & & & & \\
\hline
\end{tabular}

Tab. 1 - Fumigant toxicity of SEM 76 and Pulegone in space fumigation and columns with and without $\mathrm{CO}_{2}$.

In glass columns filled to $70 \%$ volume with wheat, it was shown that SEM 76 at a concentration of $70 \mu \mathrm{l} / \mathrm{L}$ air (equivalent to $70 \mathrm{~g} / \mathrm{m}^{3}$ ) and seven days exposure time, caused $100 \%$ kill of adults of $R$. dominica and $O$. surinamensis, but not of $T$. castaneum and $S$. oryzae.

Supplementation of $15 \% \mathrm{CO}_{2}\left(200 \mathrm{~g} / \mathrm{m}^{3}\right)$ caused reduction in the effective volatile concentration. The concentration of $50 \mu \mathrm{l} / \mathrm{L}$ air was enough to cause $96-100 \mathrm{kill}$ of all adult insects tested (Tab. 1). It should be mentioned that in order to facilitate the penetration of methyl bromide or phosphine in high bins, $200 \mathrm{~g} / \mathrm{m}^{3}$ of $\mathrm{CO}_{2}$ is needed. Efficacy of $\mathrm{CH}_{3}, \mathrm{CS}_{2}$, and $\mathrm{C}_{7} \mathrm{H}_{6} \mathrm{O}$ as fumigants for the control of stored product insects in space fumigation, $\mathrm{CH}_{3} \mathrm{I}$ was very effective against all insect stages tested. Exposure to a concentration of 3 to $5 \mu \mathrm{l} / \mathrm{L}$ air for 3 hours was lethal and caused $100 \%$ mortality of all stages of the test insects, except for T. granarium larvae (Tab. 2). Adults of $T$. 


\begin{tabular}{|c|c|c|c|c|c|c|c|c|c|}
\hline \multirow{3}{*}{ Compound } & \multirow{3}{*}{$\begin{array}{c}\text { Exposure } \\
\text { time }\end{array}$} & \multirow{3}{*}{$\begin{array}{c}\text { Conc. } \\
\mu \mathrm{L} / \mathrm{L}\end{array}$} & \multicolumn{7}{|c|}{$\%$ Mortality ( 7 days after treatment) } \\
\hline & & & \multicolumn{4}{|c|}{ Adults } & \multicolumn{3}{|c|}{ Larvae } \\
\hline & & & $\begin{array}{c}\text { Sitophilus } \\
\text { oryzae }\end{array}$ & $\begin{array}{c}\text { Rhyzopertha } \\
\text { dominica }\end{array}$ & $\begin{array}{l}\text { Orya,aphilus } \\
\text { surinamensis }\end{array}$ & \multicolumn{2}{|c|}{$\begin{array}{l}\text { Tribolium } \\
\text { castaneum }\end{array}$} & $\begin{array}{c}\text { Trogoderma } \\
\text { granarium }\end{array}$ & $\begin{array}{c}\text { Plodia } \\
\text { interpunctella }\end{array}$ \\
\hline \multirow[b]{3}{*}{$\mathrm{CH}_{3} \mathrm{I}$} & \multirow[b]{3}{*}{$3 h$} & 3 & 94 & 85 & 100 & 65 & 40 & - & 100 \\
\hline & & 4 & 100 & 100 & - & 95 & 77 & 58 & - \\
\hline & & 5 & - & - & - & 100 & 100 & 70 & - \\
\hline \multirow[b]{3}{*}{$\mathrm{CS}_{2}$} & \multirow[b]{3}{*}{1 day } & 5 & 72 & 53 & 23 & 0 & - & - & - \\
\hline & & 7 & 100 & 100 & 74 & 10 & - & - & 100 \\
\hline & & 9 & - & - & 100 & 100 & 100 & 60 & - \\
\hline \multirow[b]{2}{*}{$\mathrm{C}_{7} \mathrm{H}_{6} \mathrm{O}$} & \multirow[b]{2}{*}{1 day } & 1.5 & 79 & 16 & 39 & 0 & - & - & - \\
\hline & & 3 & 100 & 100 & 100 & 65 & 0 & 0 & - \\
\hline
\end{tabular}

Tab. 2 - Toxicity of $\mathrm{CH}_{3} \mathrm{I}, \mathrm{CS}_{2}$ and $\mathrm{C}_{7} \mathrm{H}_{6} \mathrm{O}$ against stored product insects in space fumigation. $\mathrm{CS}_{2}$ $=$ Sp. gravity 1.26 Third instar larvae were used; mortality in control was less than $5 \%$.

\begin{tabular}{|c|c|c|c|c|c|c|c|}
\hline \multirow{2}{*}{ Compound } & \multirow{2}{*}{$\begin{array}{l}\text { Conc. } \\
\mu \mathrm{l} / \mathrm{L}\end{array}$} & \multirow{2}{*}{$\begin{array}{c}\text { Exposure } \\
\text { time, h }\end{array}$} & \multirow{2}{*}{$\begin{array}{c}\text { Insects } \\
\text { cm - height } \\
\text { top - bottom }\end{array}$} & \multicolumn{4}{|c|}{$\%$ Mortality (7 days after treatment) } \\
\hline & & & & $\begin{array}{c}\text { Rhyzopertha } \\
\text { dominica }\end{array}$ & $\begin{array}{l}\text { Oryzaephilus } \\
\text { surinamensis }\end{array}$ & $\begin{array}{l}\text { Sitophilus } \\
\text { oryzae }\end{array}$ & $\begin{array}{l}\text { Tribolium } \\
\text { castaneum }\end{array}$ \\
\hline \multirow{4}{*}{$\mathrm{CH}_{3} \mathrm{I}$} & \multirow{4}{*}{5} & \multirow{2}{*}{24} & $\begin{array}{l}\text { top } \\
20\end{array}$ & 100 & 100 & 100 & 100 \\
\hline & & & $\begin{array}{c}120 \\
\text { bottom }\end{array}$ & 10 & 10 & 30 & 0 \\
\hline & & \multirow{2}{*}{72} & 20 & 100 & 100 & 100 & 100 \\
\hline & & & 120 & 95 & 75 & 80 & 0 \\
\hline \multirow{2}{*}{$\mathrm{CS}_{2}$} & \multirow{2}{*}{20} & \multirow{2}{*}{72} & 20 & 100 & 100 & 100 & 100 \\
\hline & & & 20 & \multicolumn{4}{|c|}{$100 \%$ mortality of all insects } \\
\hline
\end{tabular}

Tab. 3 - Penetration of $\mathrm{CH}_{3} \mathrm{I}$ and $\mathrm{CS}_{2}$ in $120 \mathrm{~cm}$-high columns filled with $70 \%$ wheat by gravity. Adult insects were used. Using circulation a concentration of $5 \mu \mathrm{l} / 1 \mathrm{CH}_{3} \mathrm{I}$ and exposure time of $3 \mathrm{~h}$ cause $100 \%$ kill. In the case of $\mathrm{CS}_{2} 20 \mu \mathrm{l} / \mathrm{L}$ air and exposure time of $24 \mathrm{~h}$ is needed to cause $100 \%$ kill. Mortality in untreated control was less than $5 \%$.

castaneum were found to be the most tolerant followed by $R$. dominica, S. oryzae and $O$. surinamensis. In the case of larvae, $T$. granarium was the most tolerant, followed by T. castaneum and P. interpunctella (Tab. 2).

$\mathrm{CS}_{2}$ was less effective than $\mathrm{CH}_{3} \mathrm{I}$ and needed a concentration of 7-9 $\mu \mathrm{l} / \mathrm{L}$ air for one day to achieve total mortality of all the test insects, except for T. granarium larvae. In the case of $\mathrm{CS}_{2}$ adults of $T$. castaneum were found to be the most tolerant, followed by $O$. surinamensis, $R$. dominica and $S$. oryzae. The larvae of $T$. granarium were more tolerant than T. castaneum (Tab. 2). 
$\mathrm{C}_{7} \mathrm{H}_{6} \mathrm{O}$ was less active than EOs, $\mathrm{CH}_{3} \mathrm{I}$ in space fumigation bioassays. A dosage of $3 \mu \mathrm{l} / \mathrm{L}$ air and exposure time of 1 day caused $100 \%$ adult mortality of all the tested adult insects except for T. castaneum which caused only $65 \%$ kill. The larvae of tested insects were found more tolerant than adults (Tab. 2).

In glass columns filled $70 \% \mathrm{CS}_{2}$ penetrated better than $\mathrm{CH}_{3} \mathrm{I}$, but needed higher concentration to achieve total mortality (Tab. 3). Using circulation, a concentration of $5 \mu \mathrm{l} / \mathrm{L}$ and exposure time of $3 \mathrm{~h}$, caused $100 \%$ kill of all the tested insects. In the case of $\mathrm{CS}_{2} 20 \mu \mathrm{l} / \mathrm{L}$ air an exposure time of $24 \mathrm{~h}$ is needed (results not shown). It should be mentioned that for methyl bromide fumigation the recommended concentration is 30 to $50 \mathrm{~g} / \mathrm{m}^{3} \cdot \mathrm{C}_{7} \mathrm{H}_{6} \mathrm{O}$ was found very absorptive in the grain and therefore, it is less effective than the other two fumigants in grain fumigation (results not shown).

\begin{tabular}{|c|c|c|c|c|c|c|c|c|c|}
\hline \multirow{3}{*}{ Compound } & \multirow{3}{*}{$\begin{array}{l}\text { Conc. } \\
\mu l / L\end{array}$} & \multirow{3}{*}{$\begin{array}{l}\text { Exposure } \\
\text { time, } \mathrm{h}\end{array}$} & \multicolumn{7}{|c|}{$\%$ Mortality ( 7 days after treatment) } \\
\hline & & & \multicolumn{3}{|c|}{ Larvae } & \multicolumn{4}{|c|}{ Adults } \\
\hline & & & $\begin{array}{l}\text { Tribolium } \\
\text { castanteum }\end{array}$ & $\begin{array}{l}\text { Trogoderma } \\
\text { granarium }\end{array}$ & $\begin{array}{c}\text { Plodia } \\
\text { interpunctella }\end{array}$ & $\begin{array}{l}\text { Sitophilus } \\
\text { oryzae }\end{array}$ & $\begin{array}{c}\text { Rhysopentha } \\
\text { dominica }\end{array}$ & $\begin{array}{l}\text { Onzatephitus } \\
\text { surinamensis }\end{array}$ & $\begin{array}{l}\text { Tribolium } \\
\text { castaneum }\end{array}$ \\
\hline \multirow{2}{*}{ Allyl ITC } & 1.0 & 3.0 & $\cdot$ & $\cdot$ & $\cdot$ & 100 & 100 & 100 & 100 \\
\hline & 1.5 & 3.0 & 23 & 84 & 100 & $\cdot$ & $\cdot$ & $\cdot$ & $\cdot$ \\
\hline \multirow{2}{*}{ Methyl ITC } & 1.0 & 2.5 & - & - & - & 100 & 100 & 100 & 100 \\
\hline & 1.5 & 3.5 & 100 & 81 & 100 & $\cdot$ & $\cdot$ & $\cdot$ & $\cdot$ \\
\hline \multirow{2}{*}{$\begin{array}{l}\text { Methylthio- } \\
\text { butyl ITC }\end{array}$} & 1.0 & 3.0 & $\cdot$ & - & . & 100 & 89 & 100 & 0 \\
\hline & 2.0 & 6.0 & 100 & 100 & 87 & - & 100 & - & 52 \\
\hline \multirow{2}{*}{ Ethyl ITC } & 1.0 & 3.0 & $\cdot$ & $\cdot$ & - & 100 & 100 & 100 & 0 \\
\hline & 1.5 & 3.0 & 20 & 6 & 100 & $\cdot$ & 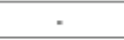 & - & 18 \\
\hline \multirow{2}{*}{ Butyl ITC } & 1.5 & 3.0 & - & - & - & 65 & 43 & 68 & 25 \\
\hline & 3.0 & 3.0 & 5.5 & 23 & 7 & 100 & 100 & 100 & 100 \\
\hline
\end{tabular}

Tab. 4 - The fumigant toxicity of four active isothiocyanates compared with methylthio-butyl ITC isolated from the plant Eruca sativa (space fumigation), third instar larvae were used.

In space fumigation, the biological activity of methylthio butyl ITC was compared with four common ITCs, namely allyl, methyl butyl and ethyl. Allyl and methyl ITCs were found to be the most potent against adults and larvae of stored product insects. In space fumigation a concentration of $1 \mu \mathrm{l} / \mathrm{L}$ air and exposure time of 3 hours were enough to kill all the tested adult insects. Methylthio butyl ITC was found also very effective, except for the T. castaneum. In the case of larvae, a higher concentration is needed to get $100 \%$ kill (Tab. 4).

\section{DISCUSSION AND CONCLUSIONS}

Our findings, as well as those of other researchers (Raja et al., 2001) suggest that certain plant essential oils and their active constituents, mainly terpenoids, have potentially high bioactivity against a range of insect and mites. They are also highly selective to insects, since they are probably targeted to the insect selective octopaminergic recep- 
tor, a non mammalian target (Kostyukovsky et al., 2002). The worldwide availability of plant essential oils and their terpenoids, their use in cosmetics and as a flavoring agent in food and beverages, is a good indication of their relative safety to warm-blood animals and humans. The ultimate goal is the introduction of these phytochemicals with low toxicity, which comply with health and environmental standards, as alternatives to methyl bromide and phosphine, for the preservation of grain and dry food.

Comparative studies with $\mathrm{CH}_{3} \mathrm{I}, \mathrm{CS}_{2}$ and $\mathrm{C}_{7} \mathrm{H}_{6} \mathrm{O}$ showed that $\mathrm{CH}_{3} \mathrm{I}$ was the most toxic compound to stored product insects, followed by $\mathrm{CS}_{2}$ and $\mathrm{C}_{7} \mathrm{H}_{6} \mathrm{O} . \mathrm{CH}_{3} \mathrm{I}$ was found less penetrative in wheat than $\mathrm{CS}_{2} \cdot \mathrm{CH}_{3} \mathrm{I}$ is known as a potent insecticide, but is toxic to humans; therefore, its use in food as a fumigant is limited. $\mathrm{CS}_{2}$, according to Winburn (1952) was one of the most effective grain fumigants, as viewed from efficiency and low cost. But it is flammable and can be used mainly as a supplement to increase the activity of other fumigants. In fact, a mixture of trichloroethylen, carbon disulphide and carbon tetrachloride (Calandrex) in a ratio 64:26:10, respectively, was developed by us and was found to be effective against stored-product insects (Polacek et al., 1960). $\mathrm{C}_{7} \mathrm{H}_{6} \mathrm{O}$ found in kernels of bitter almonds, has low toxicity to mammals, but is less effective against stored product insects than all other fumigants tested. These three compounds may play a role mainly as supplements to increase the activity of other fumigants.

ITCs were chosen for this study because of the pesticidal properties of the chemicals (Fenwick et al., 1983) and the potential use of methyl ITC as fumigant for wheat (Ducom, 1994). Our findings showed that ITCs are potential candidates because only very low concentrations are needed for the control of stored-product insects. Eruca sativa (salad rocket) is used worldwide as a food supplement and methylthio butyl ITC, the main bioactive component in this plant, has lower mammalian toxicity as compared to the other active ITC tested. The lower toxicity makes this fumigant a promising candidate for the disinfestations of grain and dry food products.

The fact that some stored product insects like the cigarette beetle, the drug store beetle, and the book louse are also regarded as cultural properties insects, makes the use of the studied fumigants potential for the control of these insects. The use of bioactive compounds, for example essential oils with $\mathrm{CO}_{2}$, or isothiocyanates, especially Methylthio butyl ITC can be used as fumigants.

We should keep in mind that it is very difficult to achieve the introduction of broad spectrum fumigants like methyl bromide or phosphine. In this context, alternative fumigants could be developed against particular species of insects, or to be used for a specific food product commodity.

\section{REFERENCES}

Ducom V., 1994 - Methyl isothiocyanate as a grain fumigant. In: Highley E., Wright E.J., Banks H.J., Champ B.R., (Eds), Proceedings of the Sixth International Working Conference of Stored Product Protection, Wallingford, UK: CABI. 91- 97.

Fenwick G., Heaney R., Mullin W., 1983 - Glucosinolates and their breakdown products in food plants. Critical Reviews in Food Science and Nutrition, 18 (2): 123-201. 
Kostyukovsky M., Rafaeli A., Gileadi C., Demchenko N., Shaaya, E., 2002 - Activation of octopaminergic receptors by essential oils constituents isolated from aromatic plants: possible mode of activity against insect pests. Pest Management Science, 58: 1-6.

Leoni O., Lori R., Palmieri S., Esposito E., Menegatti E., Cortesi R., Nastruz-Zi C., 1997 Myrosynase-generated isothiocyanate from glucosinolates: isolation, characterization and in vitro anti-proliferative studies. Bioorganic \& Medicinal Chemestry, 5 (9): 1799-1806.

Polacher K., Calderon M., ShaAya E., 1960 - A method for increasing the penetration of grain fumigant (Calandrex). Hasadeh, 40: 1-3 (In Hebrew).

Raja N., Aalbert S., Ignacimuthu S., Dorn S., 2001 - Effect of plant volatile oils in protecting stored cowpea Vigna unguiculata (L.) Walpers against Callosobruchus maculatus (F) (Coleoptera: Bruchidae) infestation. Journal of Stored Products Research, 37: 127-132.

RaJendRan S., Karanth N., 2000 - Indian Phospine resistance studies reviewed. Phospine Action News. Nigeria. October: 22-23.

ShaAya E., Kostyukovsky M., 2006 - Essential oils: potency against stored product insects and mode of action. Stewart Postharvest Review [Online], 2 (4).

ShaAya E., Kostyukovsky M., Eilberg J., Sukprakan C., 1997 - Plant oils as fumigants and contact insecticides for the control of stored-product insects. Journal of Stored Products Research, 33: 7-15.

ShaAya E., Kostyukovsky M., Ravid, 1994 - Essential oils and their constituents as effective fumigants against stored-product insects. Israel Agrisearch, 7: 133-139.

ShaAya E., Paster N., Juven B., Zisman U., Pisarev V., 1991 - Fumigant toxicity of essential oils against four major stored-product insects. Journal of Chemical Ecology, 17: 499-504.

WinBURN T.F., 1952 - Fumigants and protect ants for controlling insects in stored grain. Pest Control, 20(8): 9-11, 32, 42.

Wно, 1995 - Scientific assessment of ozone depletion: 1994. World Meteorological Organization, global ozone research and monitoring projects. Report no. 37, WMO, Geneva, Switzerland.

Eli ShaAya, The Volcani Center, Department of Food Quality and Safety, Bet Dagan 50-250, Israel.

E-mail: vtshaaya@agri.gov.il

Moshe Kostyukovsky, The Volcani Center, Department of Food Quality and Safety, Bet Dagan 50-250, Israel.

E-mail: inspect@agri.gov.il 